Ambiente \& Água - An Interdisciplinary Journal of Applied Science
ISSN 1980-993X - doi:10.4136/1980-993X
www.ambi-agua.net
E-mail: ambi.agua@gmail.com

\title{
Evaluation of electrocoagulation in the post-treatment of anaerobic wastewater of slaughterhouse and packing plant
}

\author{
ARTICLES doi:10.4136/ambi-agua.2745
}

Received: 04 May 2021; Accepted: 13 Aug. 2021

\author{
Flavia Manente da Silva ${ }^{1 *(D)}$; Fábio Orssatto ${ }^{2}{ }^{(D)}$; Eduardo Eyng1(D; \\ Laercio Mantovani Frare ${ }^{1}\left(\mathbb{D}\right.$; Ilton José Baraldi ${ }^{3}{ }^{(D}$; Leandro Fleck ${ }^{4}$ (D)
}

${ }^{1}$ Departamento de Ciências Biológicas e Ambientais. Universidade Tecnológica Federal do Paraná (UTFPR), Câmpus Medianeira, Avenida Brasil, n 4232, CEP: 85884-000, Medianeira, PR, Brazil.

E-mail: eduardoeyng@utfpr.edu.br, laerciofrare@gmail.com

${ }^{2}$ Departamento Acadêmico de Ciências Ambientais e Biológicas. Programa de Pós-Graduação em Tecnologias Ambientais. Universidade Tecnológica Federal do Paraná (UTFPR), Câmpus Medianeira, Avenida Brasil, $\mathrm{n}^{\circ}$ 4232, CEP: 85884-000, Medianeira, PR, Brazil. E-mail: orssatto@utfpr.edu.br

${ }^{3}$ Departamento Acadêmico de Alimentos. Universidade Tecnológica Federal do Paraná, Campus Medianeira, Avenida Brasil, n 4232, CEP: 85884-000, Medianeira, PR, Brazil. E-mail: baraldi@utfpr.edu.br

${ }^{4}$ Curso Superior de Tecnologia em Gestão Ambiental. Universidade Estadual de Mato Grosso do Sul (UEMS), BR 163, km 20,2, CEP: 79980-000, Mundo Novo, MS, Brazil. E-mail: fleckmissal@ gmail.com

*Corresponding author. E-mail: flavia@alunos.utfpr.edu.br

\begin{abstract}
The demand for food production brings with it the increase of effluent generation, which represents a great problem for slaughterhouses, since effluents contain higher organic load, requiring adequate treatment to decrease environmental impacts. This study examines an alternative to solve this problem: the application of electrocoagulation in the treatment of anaerobic slaughterhouse and packing plant effluents, as this promising technique is both compact and robust. The removal of color, COD and turbidity was analyzed, and the operational cost was calculated. To optimize the process, the CCRD (central composite rotatable design) methodology was used with two independent variables: electric current density and electrolysis time, obtaining a complete factorial of $2^{2}$ with 4 axial points and 4 repetitions at the central point. The most expressive removals were: $87 \%, 80 \%$ and $76 \%$ for color, COD and turbidity, respectively, the lower operational cost obtained was 0.12 US $\$ . \mathrm{m}^{-3}$. The statistical analysis allowed obtaining valid mathematical models for color removal and cost and, through the analysis of desirability, it was found that for current density of $8 \mathrm{~mA} . \mathrm{cm}^{-2}$ and time of 20 minutes it is possible to maximize color removal (84\%) and minimize the cost $\left(0.21 \mathrm{US} \$ . \mathrm{m}^{-3}\right)$.
\end{abstract}

Keywords: color, cost, COD, turbidity.

\section{Avaliação da eletrocoagulação no pós-tratamento de efluente anaeróbico de abatedouro e frigorífico de suínos}

\section{RESUMO}

A demanda por produção alimentícia traz consigo o aumento da geração de efluentes líquidos, que representa um grande problema para os frigoríficos, uma vez que tais efluentes contém alta carga orgânica, necessitando tratamento adequado para minimizar os impactos ambientais. Uma alternativa para resolver este problema é a aplicação da eletrocoagulação no tratamento de efluente anaeróbio de abatedouro e frigorífico de suínos, por ser uma técnica compacta e robusta. Foram analisadas as remoções de cor, DQO e turbidez, além do custo para 
o tratamento, sendo que para otimizar o processo utilizou-se a metodologia DCCR (delineamento composto central rotacional) com duas variáveis independentes: densidade de corrente elétrica e tempo, obtendo um fatorial completo $2^{2}$ com 4 pontos axiais e 4 repetições no ponto central. As remoções mais expressivas foram de: $87 \%, 80 \%$ e $76 \%$, para cor, DQO e turbidez, respectivamente, o menor custo obtido foi $0.12 \mathrm{US} \$ . \mathrm{m}^{-3}$. A análise estatística permitiu obter modelos matemáticos válidos para a remoção da cor e para o custo e, por meio da análise de desejabilidade, encontrou-se que para densidade de corrente de $8 \mathrm{~mA} . \mathrm{cm}^{-2}$ e tempo de 20 minutos é possível maximizar a remoção da cor $(84 \%)$ e minimizar o custo $\left(0,21 \mathrm{US} \$ . \mathrm{m}^{-3}\right)$.

Palavras-chave: cor; custo; DQO; turbidez.

\section{INTRODUCTION}

The growth of the food industry and the increase in the amount of waste generated in the process has become alarming with regard to the preservation of natural resources. As an example, one can mention the wastewater of slaughterhouses, which are constituted by fat, fibers, proteins, blood, stomach contents, among others, conferring high polluting load (Bustillo-Lecompte and Mehrvar, 2015).

Due to the great polluting power, it is necessary to carry out the treatment of these wastewater and anaerobic systems are widely used for this. The use of anaerobic digestion in the treatment of wastewater from slaughterhouses is an interesting alternative due to the generation of value-added products, such as biogas and digestate (Wang et al., 2021).

Although anaerobic treatment is efficient in the removal of organic matter, post-treatment is necessary to achieve patterns for release into rivers (Al-Qodah et al., 2019).

Many technologies can be used as post-anaerobic effluent treatment. An alternative which requires further studies is electrocoagulation, as it is a compact technology of easy operation and low maintenance cost (Al-Qodah et al., 2019).

Electrocoagulation is an electrochemical technique used to destabilize the contaminants with electric current. The reactor consists of an electrolytic cell which is formed by sacrificial metal electrodes (normally $\mathrm{Fe}$ or $\mathrm{Al}$ ), being an anode and a cathode, connected to the direct current power supply (Nidheesh et al., 2021).

Contaminant removal in the electrocoagulation occurs due to three phenomena: adsorption, coagulation, and flotation. The oxidoreduction reactions allow the formation of metallic ions and oxygen gas in the anode, and the hydrogen gas and hydroxyl in the cathode, these reactions are described below. The coagulant agent is formed by the reaction between metallic ions and hydroxyl, while the formed gases assist in bringing the flocs to the surface of the wastewater (Nidheesh et al. 2021).

At the anode:

$M_{(s)} \rightarrow M_{(a q)}^{n+}+n e^{-}$

$\mathrm{H}_{2} \mathrm{O} \rightarrow 4 \mathrm{H}_{(a q)}^{+}+\mathrm{O}_{2(g)}+4 e^{-}$

At the cathode:

$n \mathrm{H}_{2} \mathrm{O}+n e^{-} \rightarrow\left(\frac{n}{2}\right) H_{2(g)}+n O H_{(a q)}^{-}$

Aluminum is one of the most efficient electrode materials, due to the advantages over iron, like the solubility of formed flocs that are minimum in neutral $\mathrm{pH}$ and the formation of $\mathrm{Al}$ polynuclear complexes that ensure better adsorption of contaminants and colloids. 
Electrocoagulation can be considered an environmentally friendly and efficient technique to treat wastewater that contains heavy metal ions, inorganic and organic contaminants (Tegladza et al. 2021).

The use of electrocoagulation is an innovative treatment technique, since it is able to remove contaminants from wastewater, such as suspended solids, oils, toxic metals and even microorganisms without the addition of chemicals (GracePavithra et al., 2019).

Industrial-scale electrocoagulation reactors occupy small areas when compared with biological treatment systems and present significant efficiency, and can be used to replace the treatment ponds that require large superficial areas. This reduces the risks of handling chemicals when compared to conventional coagulation/flocculation. Thus, it can be said that electrocoagulation is a clean technology for the treatment of wastewater.

This study evaluated the effects of operational conditions (current density and time) of electrocoagulation on the removal of COD, color and turbidity in the post-treatment of anaerobic effluent from slaughterhouses and packing plants.

\section{METHODOLOGY}

\subsection{Sample collection}

The effluent used for the tests came from a slaughterhouse and packing plant, which has the capacity to slaughter up to 6,900 swine per day and generates around 5,865 $\mathrm{m}^{3}$ of effluent daily. This volume receives the appropriate treatment, composed of physical operation, biological treatment and finally physical-chemical treatment, and then is discarded in the river.

The sampling occurred after the anaerobic treatment of the effluent. About 30 liters were collected and stored under refrigeration.

\subsection{Experimental planning}

To verify the efficiency of the electrolytic treatment applied in anaerobic effluent, a central composite rotatable design (CCRD) was set up with 2 independent variables: current density $\left(\mathrm{mA} . \mathrm{cm}^{-2}\right)$ and electrolysis time (min), obtaining a complete factorial $2^{2}$ with 4 axial points and 4 repetitions at the central point, totaling 12 tests performed in duplicate.

The variables " $\mathrm{X}_{1}$ " and " $\mathrm{X}_{2}$ " correspond to encoded values, and the variables " $\mathrm{i}$ " and " $\mathrm{T}$ " correspond to real values for current density and electrolysis time, respectively. In the test, the current range is between 6 to $16 \mathrm{~mA} . \mathrm{cm}^{-2}$ and the electrolysis time range between 10 to 20 minutes. The relationship between both is given by Equations 1 and 2:

For current density: $1.41 i=5 X_{1}+15.51$

For electrolysis time: $1.41 T=5 X_{2}+21.15$

\subsection{Electrolytic system}

The trials were carried out in batch, for this $0.8 \mathrm{~L}$ of wastewater was added in a beaker, which was kept in constant agitation with the assistance of a magnetic stirrer. Two aluminium electrodes were used, one cathode and one anode, with dimensions of $10 \mathrm{~cm} \mathrm{high,} 5 \mathrm{~cm}$ wide and the spacing of $8.5 \mathrm{~cm}$ between them, were connected to a direct current power supply and completely immersed in the effluent. In the initial tests, aluminium electrodes were more effective than iron electrodes, and no color was added to the treated wastewater, so aluminium was chosen for the tests.

The direct current power supply is an Instrutherm brand, Model FA-3005, with maximum operating current of $5 \mathrm{~A}$, that was used to control the current density through applied electric current, considering the electrode area $\left(50 \mathrm{~cm}^{2}\right)$. The electrolytic system was represented in Figure 1. 


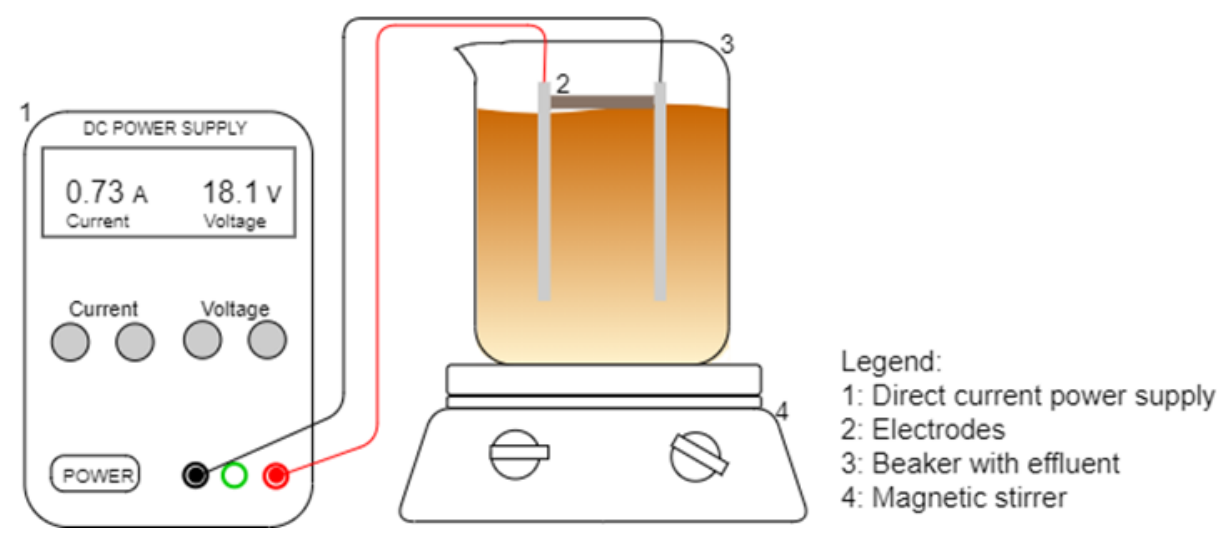

Figure 1. Representation of electrolytic system used in the tests.

\subsection{Physicochemical analyses}

The removal of color $(2120 \mathrm{C})$, turbidity $(2130 \mathrm{~B})$ and chemical oxygen demand-COD $(5220 \mathrm{D})$ was analyzed, in addition to the measurement of the $\mathrm{pH}\left(4500-\mathrm{H}^{+} \mathrm{B}\right)$ of the anaerobic effluent used in the assays. The methodologies followed the standards of APHA Standards Methods (APHA et al., 2005).

\subsection{Electrolysis cost}

To calculate the cost of each test, the methodology proposed by Orssatto et al. (2017) was used, which considers the consumption of electrodes and the consumption of electricity. Equation 3 calculates energy consumption $(\mathrm{J})$ in $\mathrm{Wh} . \mathrm{m}^{-3}$, considering: the potential difference (U) in volts; the electric current (i) in amperes; the reaction time (T) in hours and the volume of treated effluent $(\mathrm{V})$ in cubic meters:

$$
J\left(W h \cdot m^{-3}\right)=\frac{U(V) \cdot i(A) \cdot T(h)}{V\left(m^{3}\right)}
$$

The calculation of the consumed electrode mass $\left(\mathrm{M}_{\mathrm{Al}}\right)$ follows Faraday's Law and consider the parameters: electric current (i) in ampere; reaction time (T) in seconds; molar mass of aluminum (M) that is $26.98 \mathrm{~g} \cdot \mathrm{mol}^{-1}$; number of electrons involved in the reaction (e) in this case is 3; Faraday constant (F) that is 96,500 s.A.mol ${ }^{-1}$ and volume of treated effluent in cubic meters. The Equation 4 illustrates the calculus of mass consumed by volume:

$$
M_{A l}\left(k g \cdot m^{-3}\right)=\frac{i(A) \cdot T(s) \cdot M\left(g \cdot m o l^{-1}\right)}{e \cdot F\left(s \cdot A \cdot m o l^{-1}\right) \cdot V\left(m^{3}\right)}
$$

With this it is possible to calculate the total operating cost (Co) of each assay as in Equation 5 , where the coefficient " $a$ " is the cost of electricity, that is 0.14 US\$. $\mathrm{kWh}^{-1}$, and the coefficient "b" is the aluminum cost, that is $1.55 \mathrm{US} \$ . \mathrm{kg}^{-1}$.

$$
\operatorname{Co}\left(U S \$ \cdot m^{-3}\right)=a\left(U S \$ \cdot k W h^{-1}\right) \cdot J\left(k W h \cdot m^{-3}\right)+b\left(U S \$ \cdot k g^{-1}\right) \cdot M_{A l}\left(k g \cdot m^{-3}\right)
$$

\subsection{Desirability analysis}

This analysis allows us to evaluate and optimize several parameters simultaneously, obtaining an operation condition that provides the best result. The methodology proposed by Derringer and Suich is based on the calculus of the individual desirability for the variables using some parameters, namely: "U" and "L", that represent the acceptable upper and lower limits of the desirability, respectively, and " $\mathrm{T}$ " is the target value of greater desirability (Candioti et al., 2014).

In addition to these parameters, there are two other coefficients called " $\mathrm{s}$ " and " $\mathrm{t}$ " that can 
be defined as weights that determine how important it is for the individual desirability to be close to the target value (T). Assigning high values to " $\mathrm{s}$ " and " $\mathrm{t}$ " implies obtaining desirability close to 1 (that indicates de optimum value) only when the individual desirability is close to the target value T (Costa et al., 2011).

Then the global desirability (D) is calculated using the weighted geometric mean of the individual desirability, through Equation 6, where $\mathrm{d}_{\mathrm{n}}$ represents the individual desirability and $\mathrm{r}_{\mathrm{n}}$ represents the relative importance of one variable compared to another (Candioti et al., 2014).

$$
D=\left(d_{1}^{r 1} \cdot d_{2}^{r 2} \ldots d_{n}^{r n}\right)^{\frac{1}{\Sigma r i}}
$$

The desirability analysis was performed considering the valid mathematical model obtained in the regression analysis of CCRD. Desirability was calculated considering $s=5$ and $\mathrm{t}=5$.

\section{RESULTS AND DISCUSSION}

\subsection{Removal of physical-chemical parameters}

The anaerobic wastewater used for the tests presented the following concentrations of characterization: COD of 2,185 $\pm 106.70 \mathrm{mg} . \mathrm{L}^{-1}$, color of 5,000 $\pm 0.00 \mathrm{UC}$, turbidity of $434 \pm$ $7.07 \mathrm{NTU}$ and $\mathrm{pH}$ of 8.71 .

With this characterization, it was possible to estimate the removal efficiency of the physical-chemical parameters analyzed from each assay. For color, the greatest removal occurred in Test $4\left(14,6 \mathrm{~mA} . \mathrm{cm}^{-2}\right.$ and $\left.18 \mathrm{~min} 34 \mathrm{~s}\right)$, achieving efficiency around $87.00 \pm 2.40 \%$, while for COD and turbidity the highest removals were $80.60 \pm 1.35 \%$ and $76.38 \pm 0.87 \%$, respectively, observed in Test $12\left(11 \mathrm{~mA} \cdot \mathrm{cm}^{-2}\right.$ and $\left.20 \mathrm{~min}\right)$.

Test $9\left(6 \mathrm{~mA} . \mathrm{cm}^{-2}\right.$ and $\left.15 \mathrm{~min}\right)$ resulted in the lowest removal efficiency, $31.12 \pm 16.31 \%$ for the COD, $37.33 \pm 2.89 \%$ for turbidity and $59.90 \pm 0.42 \%$ for color. In Figure 2, it is possible to find the removal for all parameters (color, turbidity and COD) with the respective standard deviation for each test.

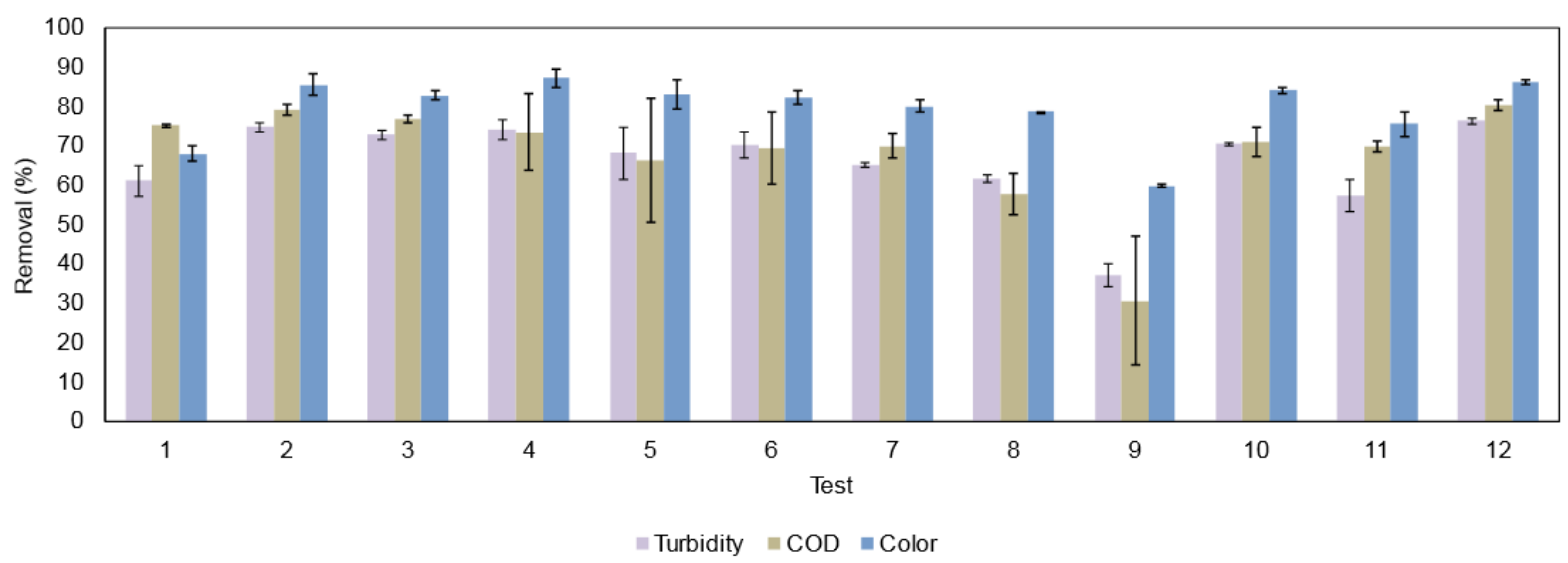

Figure 2. Graphics of removal for color, COD and turbidity.

Han et al. (2015) studied the effects of electrocoagulation on the treatment of anaerobic digester effluent fed with pig residues, finding removal of $65.6 \%$ for turbidity and energy consumption of 0.73 Wh. $\mathrm{L}^{-1}$ operating with current density of $35.7 \mathrm{~A} . \mathrm{m}^{-2}$ for 24 minutes. Mores et al. (2016) evaluated the efficiency of electrocoagulation in the treatment of effluent from an anaerobic reactor fed with pig residues. They obtained removal of $91 \%$ of turbidity using aluminum electrodes and current density of $38.9 \mathrm{~mA} . \mathrm{cm}^{-2}$ with energy consumption ranging from 2.2 to $15.3 \mathrm{kWh} . \mathrm{L}^{-1}$. The results obtained for the turbidity removal are similar to the results 
found by Han et al. (2015) and Mores et al. (2016), but the current density used in this research was lower if compared to the ones used in their study.

Lourinho et al. (2021) used raw and anaerobically pretreated swine wastewater from a pig farm to evaluate the electrochemical treatment using nickel and graphite electrodes. The results demonstrate that the treatment operating with $3 \mathrm{~V}$ and graphite electrodes was more effective than nickel electrodes, obtaining COD removal of $37.0 \%$ and $25.5 \%$ for raw and anaerobically wastewater. The authors used different electrodes; in this research, it was found that aluminum electrodes are more effective for the treatment than the graphite electrodes.

Chen et al. (2021) evaluated electrocoagulation for pretreatment of swine wastewater using iron and aluminum in the anode. The optimal conditions were the iron anode, with $2 \mathrm{~cm}$ between the electrodes, current density of $30 \mathrm{~mA} . \mathrm{cm}^{-2}$, without agitation, initial $\mathrm{pH}$ of 6.3 and reaction time of $35 \mathrm{~min}$, finding COD removal of 50.6\%. In comparison, the maximum COD removal found in this study was $80.60 \pm 1.35 \%$ operating with aluminum electrodes, lower current density and reaction time.

\subsection{Statistical analysis}

\subsubsection{Turbidity}

The statistical analysis of turbidity showed that only the variable linear $\mathrm{X}_{1}$, associated with current, is significant in a $95 \%$ confidence interval, since it was the only one that obtained $\mathrm{p}$ value below 0.05 , as can be seen in Table 1 .

Table 1. Effects of variables and regression analysis for turbidity.

\begin{tabular}{cccccc}
\hline Factor & Effect & Standard error & $\mathrm{t}(6)$ & $\mathrm{p}$-value & Coefficients \\
\hline Mean & 66.328 & 4.161 & 15.942 & 0.000 & 66.328 \\
$\mathrm{X}_{1}(\mathrm{~L})$ & 15.486 & 5.893 & 2.628 & 0.039 & 7.743 \\
$\mathrm{X}_{1}(\mathrm{Q})$ & -7.238 & 6.606 & -1.096 & 0.315 & -3.619 \\
$\mathrm{X}_{2}(\mathrm{~L})$ & 9.552 & 5.893 & 1.621 & 0.156 & 4.776 \\
$\mathrm{X}_{2}(\mathrm{Q})$ & 5.800 & 6.606 & 0.878 & 0.414 & 2.900 \\
$\mathrm{X}_{1} \mathrm{X}_{2}$ & -6.106 & 8.322 & -0.734 & 0.491 & -3.053 \\
\hline
\end{tabular}

Regarding the effects of the variables, it is noticed that only quadratic $X_{1}$ and the interaction between both $\left(\mathrm{X}_{1} \mathrm{X}_{2}\right)$ had a negative effect; that is, as the value of these variables increases the removal of turbidity tends to decrease.

For linear $\mathrm{X}_{1}$, linear $\mathrm{X}_{2}$ and quadratic $\mathrm{X}_{2}$ effect was positive, so to obtain greater removals, the value of the variables mentioned should be increased.

The mathematical model obtained through regression analysis was submitted to the variance analysis test (ANOVA). The F-calculated (2.503) is lower than the F-tabulated (4.387), indicating that the model is not valid with $95 \%$ confidence. The $\mathrm{R}^{2}$ of the analysis was 0.676 .

\subsubsection{Chemical oxygen demand}

Observing the regression analysis for COD, Table 2, it is observed that no variable was significant with $95 \%$ confidence, since all obtained p-value higher than 0.05 . It is also noticed that the variables quadratic $X_{1}$ and the interaction $X_{1} X_{2}$ presented a negative effect, and the other (linear $\mathrm{X}_{1}$, linear $\mathrm{X}_{2}$ and quadratic $\mathrm{X}_{2}$ ) have a positive effect. The same occurred for turbidity, that is, the measures to increase the removal efficiency of both parameters are the same. 
Table 2. Effects of variables and regression analysis for COD.

\begin{tabular}{cccccc}
\hline Factor & Effect & Standard error & $\mathrm{t}(6)$ & $\mathrm{p}$-value & Coefficients \\
\hline Mean & 66.122 & 6.027 & 10.971 & 0.000 & 66.122 \\
$\mathrm{X}_{1}(\mathrm{~L})$ & 14.373 & 8.536 & 1.684 & 0.143 & 7.187 \\
$\mathrm{X}_{1}(\mathrm{Q})$ & -8.477 & 9.569 & -0.886 & 0.410 & -4.238 \\
$\mathrm{X}_{2}(\mathrm{~L})$ & 2.911 & 8.536 & 0.341 & 0.745 & 1.455 \\
$\mathrm{X}_{2}(\mathrm{Q})$ & 15.695 & 9.569 & 1.640 & 0.152 & 7.847 \\
$\mathrm{X}_{1} . \mathrm{X}_{2}$ & -3.576 & 12.054 & -0.297 & 0.777 & -1.788 \\
\hline
\end{tabular}

The ANOVA of the mathematical model for the removal of COD indicated that it is not valid with $95 \%$ confidence, since the F-calculated (1.450) is lower than the F-tabulated (4.387). $\mathrm{R}^{2}$ for the analysis was 0.530 .

\subsubsection{Color}

Observing the regression analysis for color removal, Table 3, it can be seen that the variables linear $X_{1}$, linear $X_{2}$ and quadratic $X_{1}$ are significant with $95 \%$ confidence, since they obtained p-value less than 0.05 .

Table 3. Effects of variables and regression analysis for color.

\begin{tabular}{cccccc}
\hline Factor & Effect & Standard error & $\mathrm{t}(6)$ & $\mathrm{p}$-valor & Coefficients \\
\hline Mean & 81.062 & 1.733 & 46.782 & 0.000 & 81.062 \\
$\mathrm{X}_{1}(\mathrm{~L})$ & 14.058 & 2.454 & 5.728 & 0.001 & 7.029 \\
$\mathrm{X}_{1}(\mathrm{Q})$ & -6.826 & 2.751 & -2.481 & 0.048 & -3.413 \\
$\mathrm{X}_{2}(\mathrm{~L})$ & 7.981 & 2.454 & 3.252 & 0.017 & 3.990 \\
$\mathrm{X}_{2}(\mathrm{Q})$ & 2.177 & 2.751 & 0.791 & 0.459 & 1.089 \\
$\mathrm{X}_{1} \mathrm{X}_{2}$ & -6.500 & 3.466 & -1.876 & 0.110 & -3.250 \\
\hline
\end{tabular}

Regarding the effect of the variables, the behavior was similar to the removal of turbidity and COD, where the variables quadratic $\mathrm{X}_{1}$ and the interaction factor $\left(\mathrm{X}_{1} \mathrm{X}_{2}\right)$ have a negative effect, while the others have a positive effect.

The mathematical model of color removal was submitted to ANOVA, which demonstrated that the model is valid with $95 \%$ confidence, since the F-calculated (10.953) is higher than the F-tabulated (4.387). The mathematical model is represented by Equation 7 and has $R^{2}$ of 0.901.

$$
\% \text { Rem }_{\text {color }}=81.062+7.029 X_{1}-3.413 X_{1}^{2}+3.990 X_{2}+1.089 X_{2}^{2}-3.250 X_{1} X_{2}
$$

The mathematical model can be represented graphically by Figure 3, where it's perceived that the optimal region of removal is located in a current density range of 11 to $16 \mathrm{~mA} . \mathrm{cm}^{-2}$ with a time greater than $18 \mathrm{~min} 34 \mathrm{~s}$ or less than $11 \mathrm{~min} 27 \mathrm{~s}$. Furthermore it is possible to note the relation between time and current density, when these parameters increase, the color removal also increases. In Figure 3, operational conditions are shown where color removal increases, according to the variation of time and current density. 


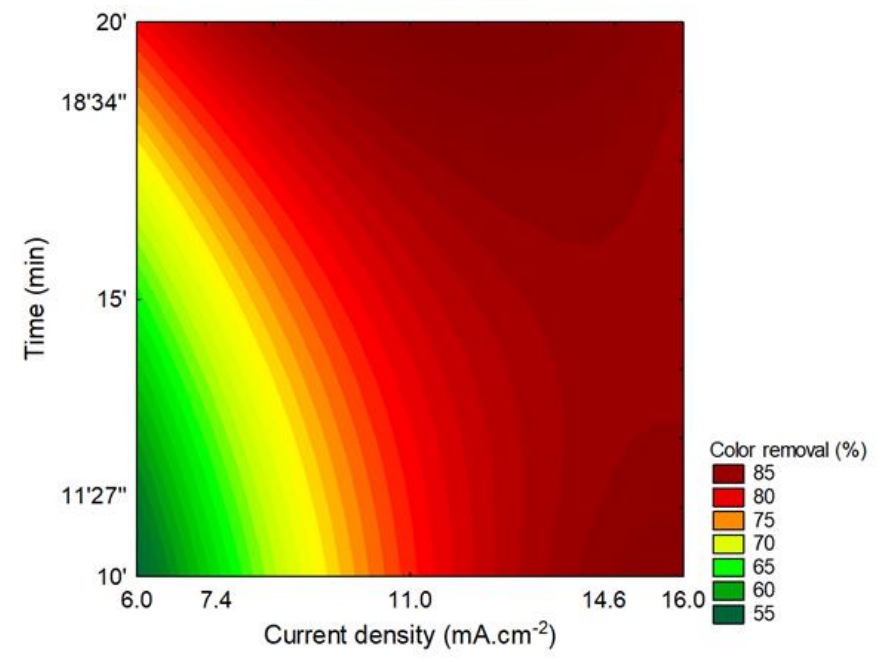

Figure 3. Contour plot for color removal.

\subsection{Operating cost}

The cost of each test is associated with the consumption of electric energy, which is determined by the applied current and electrolysis time, and the consumption of electrodes. By means of Equations 3 and 4, the consumption of electricity and the consumed mass of aluminum in each test were calculated. Considering the cost of electricity of $0.14 \mathrm{US} \$ . \mathrm{KWh}^{-1}$ and the average aluminum price of $1.5 \mathrm{US} \$ \mathrm{~kg}^{-1}$ it was possible to calculate the cost of each assay.

Trials 4 and 10 had the highest costs, around 0.74 US\$. $\mathrm{m}^{-3}$. Test 4 was performed with a current density of $14.6 \mathrm{~mA} . \mathrm{cm}^{-2}$ for $18 \mathrm{~min} 34 \mathrm{~s}$, while Test 10 was performed with a current density of $16 \mathrm{~mA} \cdot \mathrm{cm}^{-2}$ for 15 minutes. Test 9 obtained the lowest cost of 0.12 US\$. $\mathrm{m}^{-3}$ and this test was performed with a current density of $6 \mathrm{~mA} \cdot \mathrm{cm}^{-2}$ for 15 minutes.

\subsubsection{Statistical cost analysis}

Regression analysis, Table 4 , demonstrated that the variables linear $\mathrm{X}_{1}$ and linear $\mathrm{X}_{2}$ and the interaction $\left(X_{1}, X_{2}\right)$ were significant at a $95 \%$ confidence interval. In addition, they have a positive effect on the cost of each test.

The quadratic variables were not significant, but the variable quadratic $\mathrm{X}_{1}$ showed a positive effect, while the variable quadratic $\mathrm{X}_{2}$ had a negative effect.

Table 4. Effects of variables and regression analysis for cost.

\begin{tabular}{cccccc}
\hline Factor & Effect & Standard error & $\mathrm{t}(6)$ & $\mathrm{p}$-value & Coefficients \\
\hline Mean & 0.359 & 0.031 & 11.576 & 0.000 & 0.359 \\
$\mathrm{X}_{1}(\mathrm{~L})$ & 0.381 & 0.044 & 8.654 & 0.000 & 0.190 \\
$\mathrm{X}_{1}(\mathrm{Q})$ & 0.043 & 0.049 & 0.878 & 0.414 & 0.022 \\
$\mathrm{X}_{2}(\mathrm{~L})$ & 0.213 & 0.044 & 4.851 & 0.003 & 0.107 \\
$\mathrm{X}_{2}(\mathrm{Q})$ & -0.030 & 0.049 & -0.611 & 0.564 & -0.015 \\
$\mathrm{X}_{1} \cdot \mathrm{X}_{2}$ & 0.206 & 0.062 & 3.315 & 0.016 & 0.103 \\
\hline
\end{tabular}

The ANOVA of the mathematical model shows that it is valid in a $95 \%$ confidence interval, since the F-calculated (22.164) is higher than the F-tabulated (4.387). Thus, the mathematical model for cost is represented by Equation 8.

$$
\operatorname{Cost}\left(\$ . m^{-3}\right)=0.359+0.190 X_{1}+0.022 X_{1}^{2}+0.107 X_{2}-0.015 X_{2}^{2}+0.103 X_{1} X_{2}
$$

The mathematical model can be represented by Figure 4, where it can be viewed as the area where the cost is minimized. For current density values less than $11 \mathrm{~mA} . \mathrm{cm}^{-2}$, it is possible 
to obtain the lowest costs, regardless of time. Figure 4 presents the variation of cost and its relation to the increase of time and current density.

As the effect of the variable associated with current density $\left(\mathrm{X}_{1}\right)$ was approximately twice the effect of the variable associated with time $\left(\mathrm{X}_{2}\right)$, the variation of current values has more influence on the cost increase; this explains the wide range with reduced cost, even in conditions for high time.

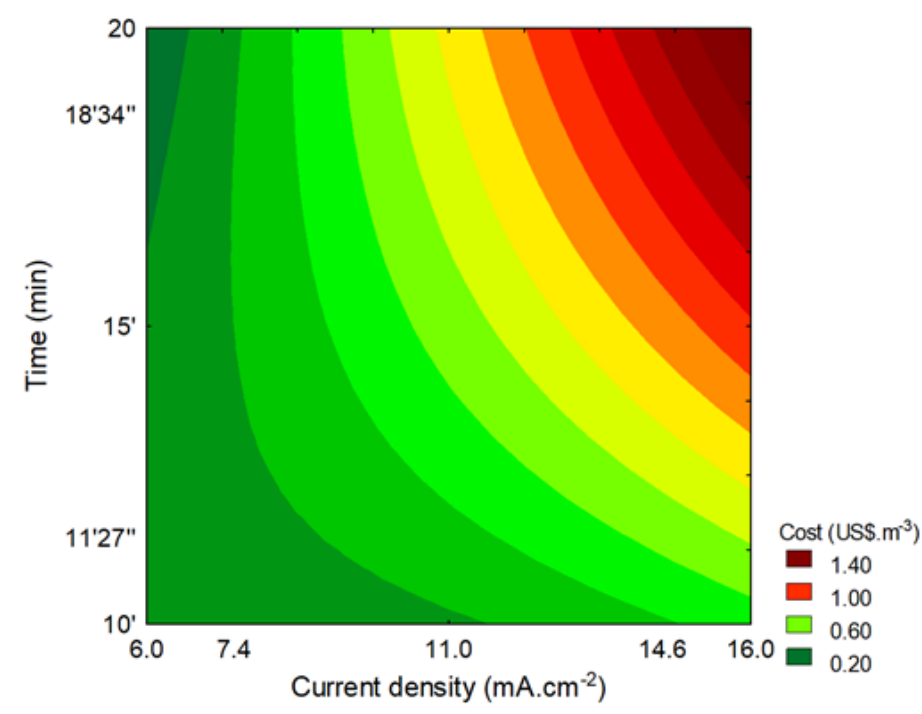

Figure 4. Contour plot for cost.

\subsection{Desirability analysis}

The mathematical models obtained in the regression analysis were only valid for color removal and operational cost, so the desirability analysis was performed using these models. Therefore, the highest removal of color was evaluated with the lowest cost.

The desirability analysis demonstrated that the optimal point is equivalent to -0.846 for current density and 1.410 for electrolysis time, in coded variables, with desirability reaching the mark of 0.999 . In real values the current density is equivalent to $8 \mathrm{~mA} . \mathrm{cm}^{-2}$ and the time of 20 minutes, reaching removal of around $84.34 \%$ of the color with a cost of 0.21 US $\$ . \mathrm{m}^{-3}$.

The desirability function is represented by Figure 5, where a track with acceptable desirability can be seen. Considering the performance of wastewater treatment on a real scale, it is interesting to obtain more operational conditions that provide optimized results.

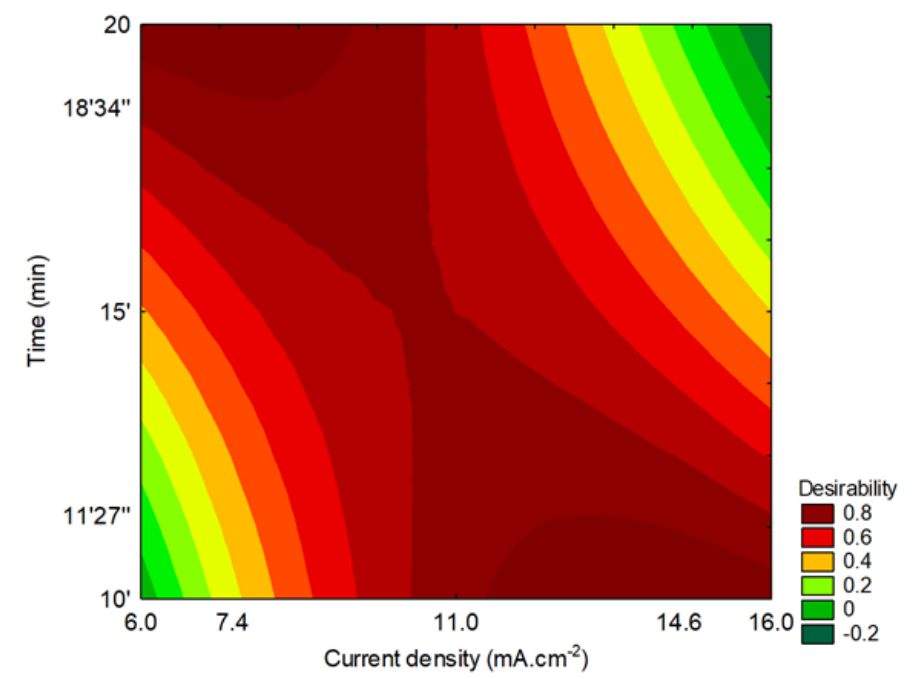

Figure 5. Contour surface for desirability. 


\section{CONCLUSION}

Observing the results, it is possible to conclude that the best removals were $87 \%$ for color in assay 4, 80.60\% for COD and 76.38\% for turbidity, both observed in assay 12 .

Thus, it is observed that the technique is efficient to treat anaerobic effluents, being an option for post-treatment in these cases, since it obtained significant removals of the analyzed parameters.

Regarding the statistical analysis, it was possible to optimize the color removal, and the optimal region for the operation is in the range of 11 to $16 \mathrm{~mA} \cdot \mathrm{cm}^{-2}$ for the current density with a time greater than $18 \min 24 \mathrm{~s}$ or less than $11 \mathrm{~min} 27 \mathrm{~s}$.

For the cost, test 9 obtained the lowest value, of $0.12 \mathrm{US} \$ . \mathrm{m}^{-3}$. Statistical analysis showed that the region with the lowest cost is between 6 and $11 \mathrm{~mA} \cdot \mathrm{cm}^{-2}$ for the electric current, regardless of the electrolysis time.

The desirability analysis allowed us to maximize color removal and minimize the cost of the condition simultaneously, and the condition for this to occur corresponds to the point where the current density should be $8 \mathrm{~mA} \cdot \mathrm{cm}^{-2}$ with reaction time of 20 minutes.

In general, the combination of anaerobic treatment combined with electrocoagulation proved to be efficient for the treatment of wastewater from slaughterhouses and packing plants. The use of electrocoagulation provided a high removal of contaminants, without the need for the addition of chemicals, besides being a compact technology with easy operation.

\section{REFERENCES}

AL-QODAH, Z.; AL-QUDAH, Y.; ASSIREY, E. Combined biological wastewater treatment with electrocoagulation as a post-polishing process: A review. Separation Science and $\begin{array}{lllllll}\text { Technology, } & \text { v. } \quad 55, \quad \text { n. } \quad 13, \quad \text { p. } 2334-2352,\end{array}$ https://doi.org/10.1080/01496395.2019.1626891

APHA; AWWA; WEF. Standard Methods for the Examination of Water and Wastewater. 21. ed. Washington, 2005.

BUSTILLO-LECOMPTE, C. F.; MEHRVAR, M. Slaughterhouse wastewater characteristics, treatment, and management in the meat processing industry: a review on trends and advances. Journal of Environmental Management, v. 161, p- 287-302, 2015 https://doi.org/10.1016/j.jenvman.2015.07.008.

CANDIOTI, L. V.; DE ZAN, M. M.; CÁMARA, M. S.; GOIOECHEA, H. C. Experimental design and multiple response optimization. Using the desirability function in analytical $\begin{array}{llllll}\text { methods development. Talanta, v. 124, p. 123-138, } 2014 . & \end{array}$ https://doi.org/10.1016/j.talanta.2014.01.034

CHEN, R.; WU, L.; ZHONG, H.; LIU, C.; QIAO, W.; WEI, C. Evaluation of electrocoagulation process for high-strength swine wastewater pretreatment. Separation and Purification Technology, v. 272, 2021. https://doi.org/10.1016/j.seppur.2021.118900

COSTA, N. R.; LOURENÇO, J.; PEREIRA, Z. L. Desirability function approach: a review and performance evaluation in adverse conditions. Chemometrics and Intelligent $\begin{array}{llllll}\text { Laboratory } & \text { Systems, } & \text { v. } & 107, & \text { p. }\end{array}$ https://doi.org/10.1016/j.chemolab.2011.04.004 
GRACEPAVITHRA, K.; JAIKUMAR, V.; KUMAR, P. S.; SUNDARRAJAN, P. A review on cleaner strategies for chromium industrial wastewater: present research and future perspective. Journal of Cleaner Production, v. 228, p. 580-593, 2019. https://doi.org/10.1016/j.jclepro.2019.04.117

HAN, Z.; WANG, L.; DUAN, L.; ZHU, S.; YE, Z.; YU, H. The electrocoagulation pretreatment of biogas digestion slurry from swine farm prior to nanofiltration concentration. Separation and Purification Technology, v. 156, n. 2, p. 817-826, 2015. https://doi.org/10.1016/j.seppur.2015.10.054

LOURINHO G.; SANTOS D. M. F.; BRITO P. S. D. Electrooxidation studies of swine effluents before and after the anaerobic digestion process. Journal of Environmental Chemical Engineering, v. 9, 2021. https://doi.org/10.1016/j.jece.2020.104712

MORES, R.; TREICHEL, H.; ZAKRZEVSKI, C. A.; KUNZ, A.; STEFFE, J.; DALLAGO, R. M. Removes of phosphorus and turbidity of swine wastewater using electrocoagulation under continuous flow. Separation and Purification Technology, 2016. http://dx.doi.org/10.1016/j.seppur.2016.07.016

NIDHEESH, P. V.; SCARIA, J.; BABU, D. S.; KUMAR, M. S. An overview on combined electrocoagulation-degradation processes for the effective treatment of water and wastewater. Chemosphere, v. 263, p. 127907, 2021, https://doi.org/10.1016/j.chemosphere.2020.127907

ORSSATTO, F.; TAVARES, M. H. F.; SILVA, F. M. DA; EYNG, E.; BIASSI, B. F.; FLECK, L. Optimization of the pretreatment of wastewater from a slaughterhouse and packing plant through electrocoagulation in a batch reactor. Environmental Technology, v. 38, n. 19, p. 2465-2475, 2017. https://doi.org/10.1080/09593330.2016.1266036

TEGLADZA, I. D.; XU, Q.; XU, K.; LV, G.; LU, J. Electrocoagulation processes: A general review about role of electro-generated flocs in pollutant removal. Process Safety and Environmental Protection, v. 146, p. 169-189, 2021, https://doi.org/10.1016/j.psep.2020.08.048

WANG, S.; SAHOO, K.; JENA, U.; DONG, H.; BERGMAN, R.; RUNGE, T. Life-cycle assessment of treating slaughterhouse waste using anaerobic digestion systems. Journal of Cleaner Production, v. 292, 2021. https://doi.org/10.1016/j.jclepro.2021.126038 